Jurnal Ekonomi dan Industri

e-ISSN: $2656-3169$

Volume 21, No.1, Januari-April 2020

p-ISSN: 0853-5248

\title{
PENGARUH KUALITAS LAYANAN DAN HARGA TERHADAP LOYALITAS PELANGGAN BOTOL MINUM HERBALIFE PADA ONLINE SHOP
}

\author{
Nazilatul Barokah 1) \\ 1) Mahasiswa Program Studi Manajemen FE UNKRIS \\ Nuridin 2) \\ 2) Dosen Program Studi Manajemen FE UNKRIS \\ Alamat: Kampus UNKRIS, Jatiwaringin Jakarta Timur \\ Email : h.nuridin58@gmail.com
}

\begin{abstract}
The purpose of this study was to determine the effect of service quality and price on customer loyalty in herbalife drinking bottles at Pondok Gede Barat. The research method uses descriptive analysis of linear regression both partially and multiplely. The findings suggest that service quality can encourage increased customer loyalty, this can be seen from the reliability of employees in handling the needs of customer orders by paying serious attention, sending orders quickly and guaranteeing a sense of security and maintaining a good relationship with customers. Prices encourage increased customer loyalty, this is because the prices offered can be affordable that are tailored to the ability of customers with quality products that are in accordance with extraordinary prices and benefits.
\end{abstract}

Keywords: Service quality, price and customer loyalty

\section{PENDAHULUAN}

Globalisasi membawa dampak yang sangat besar bagi perkembangan dunia bisnis di seluruh dunia. Kebutuhan manusia semakin meningkat dan beragam. Pemenuhan kebutuhan ini menjadikan peluang bisnis dan pasar terbuka menjadi semakin lebar, namun sebaliknya persaingan menjadi semakin ketat dan sulit diprediksikan. Teknologi zaman sekarang jauh lebih canggih dibandingkan dengan zaman dahulu. Transaksi jual beli pada zaman dahulu adalah dengan menggunakan sistem barter. Barter adalah kegiatan tukarmenukar barang yang terjadi tanpa perantaran uang, dimana penjual dan pembeli bertukar barang sesuai dengan kebutuhannya. Melalui kesepakatan bersama, kemudian penjual dan pembeli bertemu secara langsung untuk melakukan transaksi. Keberadaan internet pada saat ini memudahkan terjadinya transaksi jual beli bagi masyarakat disemua kalangan. Internet membuka peluang untuk bisnis baru dimana transaksi-transaksi bisnis kini semakin banyak dilakukan dengan melalui media elektronik. Teknologi yang telah berkembang saat ini membuka mata dunia akan sebuah kehidupan tanpa batas dimana transaksi jual beli dapat dilakukan secara online melalui internet. Pengaruh dari berkembangnya teknologi melalui internet yaitu merubah gaya hidup primitif menuju gaya hidup yang lebih modern serta dengan adanya internet menjadikan masyarakat kecenderungan dan ketergantungan beraktivitas pada dunia maya.

Berbelanja secara online mulanya hanya dapat dilakukan oleh wanita atau pria yang memiliki pendapatan dan pendidikan tinggi. Namun hal itu tidak terjadi lagi pada saat ini, karena kemudahan jangkauan dan transaksi yang ditawarkan oleh online shop dapat menarik banyak konsumen tanpa adanya perbedaan status sosial. Kegiatan berbelanja tidak 
lagi menjadi kegiatan yang direncanakan, dimana konsumen tidak perlu mengunjungi pusat perbelanjaan untuk membeli suatu barang. Dengan begitu dapat menghemat dana yang tidak perlu mengantri dalam melakukan transaksi jual beli. Manfaat keberadaan online shop melalui internet yaitu sebagai media promosi suatu produk yang akan memberikan keuntungan bagi penjual karena produknya dikenal di seluruh dunia dan memberikan keuntungan bagi pembeli yang dapat lebih menghemat waktu, biaya, tenaga serta bisa dilakukan dimana saja dan kapan saja.

Online shop adalah pembelian suatu barang atau jasa dari mereka yang menjual barang atau jasa melalui internet dengan penjual dan pembeli tidak bertemuatau melalukan kontak fisik secara langsung, dimana penjual menampilkan produk yang ditawarkan, harga yang tertera, kecepatan layanan yang diberikan melalui tampilan pada gambar yang diunggah di suatu website atau toko maya. Online shop serupa dengan pasar modern atau tradisional yang ada di dunia nyata, perbedaannnya hanya pada proses transaksi jual belinya yaitu dengan menggunakan jaringan internet yang memudahkan para pembeli melihat pilihan barang, pelayanan yang diberikan dan harga, cukup hanya membuka web online shop dengan menggunakan sambungan internet. Hal ini membuat banyak penjual online shop berlomba-lomba menawarkan produknya dengan berbagai cara yang menarik konsumen untuk berbelanja. Berkembangnya online shop pun membuat banyaknya media sosial baru bermunculan yang akan mendukung kegiatan dari bisnis jual beli tersebut.

Ketika kita ingin menjalankan usaha online shop dengan berjualan produk di internet, maka sebaiknya produk tersebut adalah barang yang cukup banyak peminatnya. Memang sebagian besar produk yang dibutuhkan manusia saat ini bisa terjual via online, tapi akan lebih baik bila kita memilih produk jualan online yang paling laku di Indonesia.

Lalu bagaimana cara mengetahui informasi tentang barang yang paling dicari di toko online saat ini? Ada banyak cara, salah satunya adalah dengan melihat trend di internet, misalnya melihat jualan online yang paling sering muncul di media sosial seperti Instagram dan Facebook. Kita juga bisa mendapatkan informasi produk terlaris di online shop saat ini dengan memperhatikan produk-produk di situs jualan online yang paling laris saat ini, misalnya marketplace Tokopedia, Bukalapak, Blibli, Lazada, dan lainnya.

Menurut maxmanroe.com terdapat delapan barang jualan online yang paling laku di Indonesia saat ini produk terlaris dan paling dicari di online shop Indonesia. Produk fashion menduduki urutan pertama yang paling banyak dicri via online, dimana terget yang paling dominan adalah wanita dewasa, alasannya karena wanita dewasa sangat suka melihat-lihat gambar produk via online dan mudah terpengaruh untuk segera membeli. urutan selanjutnya yaitu pencarian produk kecantikan, lagi-lagi produk untuk wanita adalah barang yang paling laku dijual di internet termasuk produk kecantikan. Beberapa produk kecantikan yang paling laku dijual online saat ini adalah, produk pemutih kulit wajah, obat jerawat, masker penghalus kulit wajah, kosmetik anti angin, pelangsing tubuh, perawatan rambut dll. Urutan ketiga adalah produk herbal untuk kesehatan dan vitalitas, sekarang produk-produk herbal sangat laris dijual di internet. Berbagai produk herbal yang dijual secara online tersebut memiliki manfaat dan kegunaan masing-masing. Ada produk herbal untuk pengobatan, untuk menjaga kesehatan dan untuk vitalitas, khususnya untuk pria dewasa. Beberapa jenis produk herbal yang laku dijual secara online adalah: produk herbal pelangsing tubah, penambah berat badan, herbal untuk vitalitas pria dan wanta dewasa. Produk gadget laris manis dijual online menepatai urutan keempat, dijaman digital, semua yang berhubungan dengan dunia digital pasti butuh gadget, jadi tidak heran bila gadget adalah salah satu barang yang paling laku dijual di online shop saat ini. Jadi tidak heran bila gadget adalah salah satu barang yang paling laku dijual via online shop. Ada beberapa jenis produk gadget yang banyak peminatnya saat ini, diantanya: 
smartphone, tablet, kamera digital, laptop/PC, fidget spinner, drone. Urutan kelima adalah produk rumah tangga, dahulu produk rumah tangga dibeli secara offline, sekarang sangat laku diberbagai toko online, produk rumah tangga seperti kompor gas, blender, mesin jahit mini, pemanggan roti hingga yang lainnya. kemudian urutan keenam adalah produk unik dan lucu, produk ini cukup banyak dicari di internet. Permintaan akan barang-barang unik dan lucu ini berawal dari beberapa website yang mempromosikan produk menarik yang belum pernah kita temukan sebelumnya, produk unik diantaranya adalah tongsis, lampu tidur unik, kaca mata nigh vision, dll. Kedudukan ketujuh adalah produk makanan, jenis makanan bisa dijual secara online saat ini karena faktor kadaluarsa. Namun, ada cukup banyak jenis makanan yang laris dijual di internet. Seperti aneka cake dan cookies, frozeen food, snack, produk bahan makanan. Yang terakhir adalah produk mainan anak, sekarang produk mainan anak sudah mendapat porsi yang cukup besar dalam hal penjualan secara online. Alasannya, kemudahan dalam melihat produk, jenis mainan sangat beragam, kemudahan transaksi dan biasanya harganya cenderung lebih murah. Contoh jenis mainan anak adalah: mainan action figure, mainan alat musik, mainan ketrampilan, mainan edukasi, dan sebagainya. Dari berbagai produk yang dijual melalui online shop seperti tersebut di atas, toko online saya yang sudah berdiri sejak tahun 2016 sudah banyak pelanggannya, toko online saya yang bergerak dalam jual botol minum herbalife.

Berikut ini disajikan data jumlah pelanggan yang membeli botol minum herbalife

\begin{tabular}{|c|c|}
\hline Tahun & Dolonor \\
\hline Tanun & Pelanggan Unitne \\
\hline 2016 & 463 \\
\hline 2017 & 674 \\
\hline 2018 & 863 \\
\hline Jumlah & 2000 \\
\hline
\end{tabular}

Sumber: data online, 2018.

Pada Tabel 1, terlihat bahwa jumlah pelanggan yang membeli botol minum herbalife via online mengalami kenaikan dari tahun 2016 sampai tahun 2018. Selain itu dapat dilihat juga bahwa pada tahun 2016, pelanggan yang membeli botol minum herbalife masih belum banyak dikarenakan pada tahun 2106 merupakan tahun awal mulanya botol minum herbalife didirikan. Kemudian pada tahun berikutnya, yaitu pada tahun 2107 mengalami peningkatan yang cukup menggembirakan karena mulai banyak pengguna internet yang mengetahui akun online shop milik botol minum herbalife. Tahun 2018 pelanggan yang membeli botol minum herbalife mengalami kenaikan yang signifikan, yang berati para pengguna internet semakin mengetahui bahwa ada produk botol minun herbalife.

Berdasarkan Tabel 1, dapat disimpulkan bahwa botol minum herbalife mengalami perkembangan pesat dengan bertambahnya pelanggan dari tahun ketahun berikutnya. Jumlah pelanggan yang tinggi, tidak memungkinkan adanya persaingan pada industri sejenis. Persaingan yang ketat dalam industri botol minum herbalife, tentunya perusahaan harus menetapkan strategi pemasaran yang tepat sehingga dapat mencapai target yang diharapkan. Salah satu strategi yang digunakan oleh perusahaan botol minum herbalife yaitu dengan melalukan kegiatan endorse, yaitu memberikan layanan yang prima dan tepat waktu serta harga yang dapat dijangkau oleh para pelanggan. Dimana dengan kegiatan tersebut, permintaan dari pelanggan terus meningkat hingga saat ini karena banyak pelanggan yang sudah percaya dan merasa loyal. 
Loyalitas pelanggan menurut Tjiptono (2015) adalah: "loyalitas pelanggan sebagai komitmen pelanggan terhadap suatu merek, toko, pemasok berdasarkan sikap yang sangat positif dan tercermin dalam pembelian ulang yang konsisten." Kemudian sebelum memutuskan untuk menjadi pelanggan yang loyal terhadap suatu barang atau jasa, ada beberapa faktor yang menjadi pertimbangan yaitu kualitas layanan. Menurut menurut Lupiyoadi (2013), "Kualitas layanan adalah seberapa jauh perbedaan antara kenyataan dan harapan pelanggan yang akan mereka terima atau peroleh". Jadi, dapat disimpulkan bahwa kualitas layanan merupakan segala aspek jasa atau layanan yang disampaikan suatu perusahaan dengan tujuan memenuhi ekspektasi para konsumen berupa kemudahan, kecepatan, kemampuan, hubungan, dan keramahan dalam melakukan transaksi jual beli. Kualitas layanan dilihat dengan melakukan perbandingan antara pandangan konsumen atas layanan yang nyata diterima atau diperoleh dengan layanan yang sesungguhnya diberikan terhadap suatu perusahaan.

Faktor yang mempengaruhi terbentuknya loyalitas pelanggan adalah harga yang ditawarkan kepada para konsumen, harga menjadi pertimbangan bagi para konsumen untuk membeli produk yang diinginkannya. Harga menurut Kotler (2013) adalah "jumlah semua yang diberikan oleh pelanggan untuk mendapatkan keuntungan dari memiliki atau menggunakan suatu produk atau jasa". jika konsumen menerima tawaran berarti harga tersebut sudah tepat.

Berdasarkan uraian tersebut di atas, kepercayaan terhadap online shop muncul karena konsumen yakin bahwa online shop mengacu pada penilaian adanya mekanisme keamanan yang memadai. Kecenderungan masyarakat untuk berbelanja secara online mengurangi tingkat kewaspadaan yang terbukti dengan banyaknya kasus penipuan dengan modus online shopping, terumata disebabkan karena penjual dan pembeli tidak bertatap secara langsung. Dengan demikian, sistem kepercayaan menjadi modal utama dalam setiap transaksi jual beli online.

Tujuan penelitian ini adalah untuk mengetahui pengaruh kualitas layanan dan harga terhadap loyalitas pelanggan botol minum Herbalife pada Online Shop.

\section{LANDASAN TEORI}

\section{Loyalitas Pelanggan}

Menurut Tjiptono (2015) loyalitas pelanggan adalah "komitmen pelanggan terhadap suatu merek, took atau pemasok berdasarkan sifat yang sangat positif dalam pembelian jangka panjang”. Dari pengertian ini dapat disimpulkan bahwa kesetiaan pelanggan tercipta karena adanya kombinasi dari kepuasan dan keluhan. Sedangkan menurut Griffin (2005) Konsep lain mengenai loyalitas pelanggan menyebutkan bahwa konsep "loyalitas lebih mengarah kepada perilaku (behavior) dibandingkan dengan sikap (attitude) dan seorang pelanggan yang loyal karena memperhatikan perilaku pembelian yang dapat diartikan sebagai pola pembelian yang teratur dan dalam waktu yang lama, yang dilakukan oleh unit-unit pembuat atau pengambil keputusan". Lebih lanjut menurut Delgado dan Munuera (2005) mendefinisisi customer loyalty "sebagai sebuah ukuran keterkaitan pelanggan terhadap suatu produk yang terwujud pada satu keinginan untuk membeli ulang dan keinginan untuk merekomendasikan kepada orang lain". Lau dan Lee (1999) mengarah pada konseptualisasi yang lebih kuat dengan memandang customer loyalty sebagai "sebuah hubungan antara sikap relatif individu yang mengarah pada sebuah kesatuan (merk, pelayanan, toko, dan vendor) dengan pembelian ulang".

Mempertahankan loyalitas pelanggan berarti perusahaan mengeluarkan biaya lebih sedikit daripada harus memperoleh satu pelanggan yang baru. Loyalitas akan memberikan 
banyak keuntungan bagi perusahaan, termasuk didalamnya perulangan pembelian dan rekomendasi mengenai merk tersebut kepada teman dan kenalan ( Lau dan Lee, 1999 ).

Menurut Robinette (2001), faktor-faktor yang mempengaruhi loyalitas pelanggan adalah: 1). "Perhatian; Perusahaan harus dapat melihat dan mengatasi segala kebutuhan, harapan, maupun permasalahan yang dihadapi oleh pelanggan. Dengan perhatian itu, pelanggan akan menjadi puas terhadap perusahaan dan melakukan transaksi ulang dengan perusahaan, dan pada akhirnya mereka akan menjadi pelanggan perusahaan yang loyal. Semakin perusahaan menunjukkan perhatiannya, maka akan semakin besar loyalitas pelanggan itu muncul. 2). Kepercayaan; Kepercayaan timbul dari suatu proses yang lama sampai kedua belah pihak saling mempercayai. Apabila kepercayaan sudah terjalin di antara pelanggan dan perusahaan, maka usaha untuk membinanya akan lebih mudah, hubungan perusahaan dan pelanggan tercermin dari tingkat kepercayaan para pelanggan. Apabila tingkat kepercayaan pelanggan tinggi, maka hubungan perusahaan dengan pelanggan akan menjadi kuat. Salah satu cara yang dapat dilakukan perusahaan dalam membina hubungan dengan pelanggan, yaitu segala jenis produk yang dihasilkan perusahaan harus memiliki kualitas atau kesempurnaan seperti yang seharusnya atau sebagaimana dijanjikan, sehingga pelanggan tidak merasa tertipu, yang mana hal ini dapat mengakibatkan pelanggan berpindah ke produk pesaing. 3). Perlindungan; Perusahaan harus dapat memberikan perlindungan kepada pelanggannya, baik berupa kualitas produk, pelayanan, komplain ataupun layanan purna jual. Dengan demiian, pelanggan tidak khawatir perusahaan dalam melakukan transaksi dan berhubungan dengan perusahaan, karena pelanggan merasa perusahaan memberikan perlindungan yang mereka butuhkan. 4). Kepuasan akumulatif; Kepuasan akumulatif adalah keseluruhan penilaian berdasarkan total pembelian dan konsumsi atas barang dan jasa pada suatu periode tertentu. Kepuasan akumulatif ditentukan oleh berbagai komponen seperti kepuasan terhadap sikap agen dan kepuasan terhadap perusahaan itu sendiri. Oleh karena itu, perusahaan harus dapat memberikan rasa puas kepada pelanggan dalam melakukan segala transaksi dengan perusahaan, sehingga dalam hal ini perusahaan harus memperhatikan dan meningkatkan fungsi dan kegunaan dari segala fasilitas dan sumber daya yang dimiliki agar pelanggan dapat memanfaatkannya kapan saja dan dimana saja".

Brown dalam Hurriyati (2010), mengungkapkan bahwa loyalitas pelanggan terdiri dari tiga tahap sebagai berikut: 1). "The Courtship. Pada tahap ini, hubungan yang terjadi antara perusahaan dengan pelanggan sebatas penawaran produk/jasa dan harga yang diberikan pesaing lebih baik, maka mereka akan pindah. 2). The Relationship. Pada tahapan ini, tercipta hubungan yang erat antara perusahaan dan pelanggan. Loyalitas yang terbentuk tidak lagi didasarkan pada pertimbangan produk/jasa dan harga, walaupun tidak ada jaminan pelanggan tidak akan melihat pesaing. Selain itu tahap ini terjadi hubungan yang saling menguntungkan bagi kedua belah pihak. 3). Marriage. Pada tahapan ini hubungan jangka panjang telah tercipta dan keduanya tidak dapat dipisahkan. Loyalitas tercipta akibat adanya kesenangan dan ketergantungan pelanggan pada perusahaan".

Indikator loyalitas yang diungkapkan Griffin (dalam Hurriyati, 2010), ada beberapa indikator yang digunakan untuk mengukur variabel loyalitas pelanggan adalah: 1). "Melakukan pembelian ulang secara teratur. Konsumen melakukan pembelian secara kontinue pada suatu produk tertentu. 2). Melakukan pembelian di luar lini produk/jasa. Konsumen tidak hanya membeli jasa atau produk utama tetapi konsumen juga membeli lini produk dan jasa dari perusahaan yang sama. 3). Merekomendasikan produk kepada orang lain. Dimana konsumen melakukan komunikasi dari mulut ke mulut berkenaan dengan produk tersebut. 4). Menunjukkan kekebalan dari daya tarikan produk sejenis dari pesaing. 
Konsumen menolak untuk menggunakan produk atau jasa alternatif yang ditawarkan oleh pesaing".

\section{Kualitas Pelayanan}

Menurut Tjiptono (2015), mengungkapkan kualitas pelayanan adalah "sistem manajemen strategis dan integratif yang melibatkan semua manajer dan karyawan serta menggunakan metode kualitatif dan kuantitatif untuk memperbaiki secara berkesinambungan atas proses organisasi agar dapat memenuhi dan melebihi kebutuhan, keinginan dan harapan pelanggan". Kualitas pelayanan berpusat pada suatu kenyataan yang ditentukan oleh pelanggan. Interaksi strategi pelayanan, sistem pelayanan dan sumber daya manusia serta pelanggan akan sangat menentukan keberhasilan dari manajemen perusahaan.

Suatu cara perusahaan untuk tetap dapat unggul bersaing adalah memberikan jasa dengan kualitas yang lebih tinggi dari pesaingnya secara konsisten. Harapan pelanggan dibentuk oleh pengalaman masa lalunya, pembicaraan dari mulut ke mulut serta promosi yang dilakukan oleh perusahaan jasa, kemudian dibandingkannya. hal terpenting adalah bersedia mendengarkan pelanggan, perusahaan melakukan hubungan dengan pelanggan dengan cara memenuhi harapan serta perhatian kepada pelanggan, sedangkan menurut Supranto (2011), mengemukakan kualitas pelayanan/jasa "merupakan suatu cara perusahaan jasa untuk tetap dapat unggul bersaing adalah memberikan jasa dengan kualitas yang lebih tinggi dari pesaingnya secara konsisten". Keunikan suatu produk jasa adalah tergantung dari keunikan serta kualitas yang diperlihatkan oleh jasa tersebut, apakah sudah sesuai dengan harapan dan keinginan pelanggan.

Berdasarkan pendapat di atas dapat saya simpulkan bahwa kualitas pelayanan adalah suatu cara perusahaan untuk bersaing dalam mengungulkan perusahaannya dalam bidang pelayanan jasa, dimana seluruh karyawan dalam perusahaan tersebut harus ikut seta dalam melakukan pelayanan kepada pelanggan yang melakukan interaksi pada perusahaan tersebut.

Banyak cara yang dapat dilakukan untuk meningkatkan kualitas pelayanan, di antaranya adalah dengan melakukan evaluasi dan perbaikan-perbaikan yang dilakukan secara berkala. Beberapa cara yang dapat dilakukan untuk meningkatkan kualitas pelayanan adalah sebagai berikut : 1). "Mendapatkan umpan balik dari pelanggan. Banyak cara yang dapat dilakukuan untuk mendapatkan feedback dari pelanggan, diantaranya seperti mengadakan survei kepada pelanggan, dan follow up kepada pelanggan setelah memberikan pelayanan, cara ini dapat dilakukan melalui email. Cara lainnya adalah uji coba produk kepada pelanggan, aktif di sosial media, memberikan diskon atau benefit lain kepada pelanggan atas penghargaan masukan yang telah diberikan, serta memanfaatkan teknologi untuk memantau perkembangan usaha seperti melalui website, google analytics, dan lain sebagainya. 2). Melakukan evaluasi perusahaan. Cara-cara yang dapat dilakukan untuk melakukan evaluasi diantaranya adalah melalui survei dengan cara berfokus pada hal-hal yang paling penting untuk diketahui. Survei dapat dilakukan untuk mengetahui rasa empati atau kepedulian kepada pelanggan, mengukur tingkat kemampuan suatu perusahaan terkait kehandalan dan cepat tanggap, serta mengetahui pelayanan dan kualitas produk berdasarkan pengalaman konsumen secara langsung seperti fungsi produk, tingkat kebersihan, penampilan karwayan, dan lain sebagainya. 3). Memperbaiki pelayanan perusahaan. Memperbaiki kualitas pelayanan dapat dilakukan dengan cara memberikan standar pelayanan perusahaan yang jelas kepada karyawan, melatih karyawan agar menjadi seseorang yang bertanggung jawab, cepat tanggap, dan memiliki etos kerja yang tinggi. Jika memungkinkan, dapat dengan memberikan bonus kepada karyawan yang berprestasi. 
Selain itu, memberikan kemudahan kepada pelanggan dalam menyampaikan masukannya adalah hal yang perlu untuk dilakukan. Namun akan lebih baik apabila semua usaha perbaikan kualitas pelayanan perusahaan ini agar dilakukan secara berkelanjutan".

Menurut Parasuraman yang dikutip oleh Tjiptono (2015) terdapat lima indikator dalam kualitas pelayanan sebagai berikut: 1). "Reliabilitas; Berkaitan dengan kemampuan perusahaan untuk memberikan pelayanan yang akurat sejak pertama kali tanpa melakukan kesalahan apapun dan menyampaikan jasanya sesuai dengan waktu yang disepakati. 2). Daya tanggap; Berhubungan dengan kesediaan dan kemampuan karyawan untuk membantu para konsumen dan merespon permintaan mereka, serta menginformasikan kapan jasa akan diberikan dan kemudian memberikan jasa secara cepat. 3). Jaminan; Perilaku karyawan yang mampu menumbuhkan kepercayaan konsumen terhadap perusahaan dan perusahaan bisa menciptakan rasa aman bagi para konsumennya. Jaminan juga berarti bahwa para karyawan selalu bersikap sopan dan menguasai pengetahuan dan keterampilan yang dibutuhkan untukmenangani setiap pertanyaan atau masalah konsumen. 4). Empati; Menyatakan bahwa perusahaan memahami masalah para konsumennya dan bertindak demi kepentingan konsumen, serta memberikan perhatian personal kepada para konsumen dan memiliki jam operasi yang nyaman. 5). Bukti Fisik; Berkenaan dengan daya tarik fasilitas fisik, peralatan/perlengkapan yang lengkap, dan material yang digunakan perusahaan bersih, serta penampilandari karyawan rapi”.

\section{Harga}

Harga merupakan "salah satu atribut paling penting yang dievaluasi oleh konsumen, dan manajer perlu benar-benar menyadari peran harga tersebut dalam pembentukan sikap konsumen". (Mowen \& Minor, 2002). Dalam situasi tertentu para konsumen sangatlah sensitif terhadap harga, sehingga harga yang relatif tinggi dibanding para pesaingnya dapat mengeliminasi produk dari pertimbangan konsumen. Dalam arti yang paling sempit, harga adalah "jumlah uang yang dibebankan atas suatu produk atau jasa" (Kotler, 2013). Dari sudut pandang produsen harga merupakan komponen yang berpengaruh langsung terhadap laba perusahaan dalam artian merupakan pendapatan. Sementara itu, dari sudut pandang konsumen harga sering kali digunakan sebagai indikator nilai bilamana harga tersebut dihubungkan dengan manfaat yang dirasakan atas suatu produk atau dalam arti kata harga merupakan pengorbanan bagi konsumen dalam mendapatkan suatu produk.

Namun secara sederhana harga dapat diartikan "sebagai sejumlah uang (satuan moneter) dan atau aspek lain (non moneter) yang mengandung kegunaan tertentu yang diperlukan untuk mendapatkan suatu produk/jasa". Menurut pendapat Swastha (2011) bahwa "harga sering dijadikan indikator kualitas bagi pelanggan dimana orang sering memilih harga yang lebih murah". Dalam hal ini, yang dimaksud murah adalah "kesesuaian dengan kualitas jasa pelayanan dengan harga yang harus dibayarkan". Selain itu dapat juga diartikan harga termurah untuk kualitas jasa yang terbaik. Sehingga dengan yang harga murah memiliki asosiasi antara kualitas yang diperoleh baik dengan kepuasan pelanggan yang baik atas jasa tersebut.

Berdasarkan beberapa definisi harga maka dapat disimpulkan bahwa harga merupakan nilai dari suatu barang atau jasa yang diukur dengan uang yang dibebankan kepada pembeli atau konsumen untuk memperoleh barang atau jasa tersebut

Harga memiliki fungsi sebagai alat ukur nilai suatu barang, cara membedakan suatu barang, menentukan jumlah barang yang akan diproduksi dan pembagiannya kepada konsumen, berikut ini adalah beberapa fungsi harga secara umum: 1). "Menjadi acuan dalam memperhitungkan nilai jual suatu barang atau jasa. 2). Untuk membantu aktivitas transaksi, dimana harga yang sudah terbentuk akan mempermudah proses jual-beli. 
3). Penetapan harga yang tepat akan memberikan keuntungan bagi penjual atau produsen. 4). Menjadi salah satu acuan bagi konsumen dalam menilai kualitas suatu barang atau jasa. 5). Membantu konsumen dalam pengambilan keputusan berkaitan dengan manfaat produk dan daya beli konsumen".

Menurut Kotler dan Amstrong (2012) menjelaskan ada empat indikator yang mencirikan harga, adalah: 1). "Keterjangkauan harga. Konsumen bisa menjangkau harga yang telah ditetapkan oleh perusahaan. Produk biasanya ada beberapa jenis dalam satu merek dan harganya juga berbeda dari termurah sampai termahal. Dengan harga yang ditetapkan para konsumen banyak yang membeli produk. 2). Harga sesuai kemampuan atau daya saing harga. Konsumen sering membandingkan harga suatu produk dengan produk lainnya. Dalam hal ini mahal murahnya harga suatu produk sangat dipertimbangkan oleh konsumen pada saat akan membeli produk tersebut. 3). Kesesuaian harga dengan kualitas produk. Harga sering dijadikan sebagai indikator kualitas bagi konsumen orang sering memilih harga yang lebih tinggi diantara dua barang karena mereka melihat adanya perbedaan kualitas. Apabila harga lebih tinggi orang cenderung beranggapan bahwa kualitasnya juga lebih baik. 4). Kesesuaian harga dengan manfaat. Konsumen memutuskan membeli suatu produk jika manfaat yang dirasakan lebih besar atau sama dengan yang telah dikeluarkan untuk mendapatkannya. Jika konsumen merasakan manfaat produk lebih kecil dari uang yang dikeluarkan maka konsumen akan beranggapan bahwa produk tersebut mahal dan konsumen akan berpikir dua kali untuk melakukan pembelian ulang".

\section{METODE PENELITIAN}

Penelitian ini untuk menjelaskan hubungan kausalitas variabel kualitas pelayanan dan harga. Data yang digunakan dalam penelitian ini merupakan data primer melalui pengisian kuesioner kepada para pelanggan. Metode analisis yang digunakan adalah metode analisis regresi linear sederhana dan berganda. Populasi dalam penelitian ini adalah pelanggan yang order langsung kepemilik sebanyak 160 orang yang membeli botol minum herbalife di Pondok Gede Barat,

Penelitian ini menggunakan ukuran sampel dengan rumus Slovin (Umar, 2011). Berdasarkan perhitungan rumus slovin tersebut diambil menjadi sampel sebanyak 62 pelanggan. Teknik pengambilan sampel yang digunakan dalam penelitian ini adalah simple random sampling yaitu peneliti dalam memilih sampel dengan memberikan kesempatan yang sama kepada semua anggota populasi untuk ditetapkan sebagai anggota sampel.

\section{HASIL PENELITIAN DAN PEMBAHASAN}

\section{Uji Instrumen Data}

Berdasarkan uraian tersebut di atas, maka untuk dapat menentukan apakah variabel kualitas pelayanan dan harga dapat dijadikan pengukur terhadap loyalitas pelanggan Botol Minum Herbalife Pada Online Shop. Namun sebelumnya data diolah terlebih dahulu dan dilakukan pengujian terhadap varibel yang digunakan yaitu kualitas pelayanan dan harga untuk mengetahui apakah data tersebut akurat dan dapat dipercaya.

\section{Uji Validitas}

Pengujian validitas ini dilakukan untuk menguji apakah tiap butir pernyataan telah mewakili indikator yang akan diteliti, persyaratan minimum untuk dapat dikatakan valid adalah $r=0,30$. Jadi, apabila korelasi antara butir-butir item pernyataan dengan skor total 
kurang dari 0,30, maka butiran dalam instrumen tersebut dapat dikatakan tidak valid. Uji validitas dilakukan dengan melihat korelasi antara skor masing-masing item pernyataan dengan skor total.

\section{Uji Validitas Instrumen Variabel}

Dari perhitungan koefisien korelasi skor tiap butir pernyataan dari 65 responden tentang instrument kualitas pelayanan, dengan jumlah 10 pernyataan; instrumen harga 8 pernyataan dan instrumen loyalitas pelanggan 8 pernyataan dengan total skor setiap responden diperoleh hasil yang disajikan dalam tabel sebagai berikut:

Tabel 2: Hasil Uji Validitas Instrumen Variabel

\begin{tabular}{|c|c|c|c|c|c|}
\hline \multirow[b]{2}{*}{ Pernyataan } & \multicolumn{3}{|c|}{ R Hitung } & \multirow[b]{2}{*}{ R Kritis } & \multirow[b]{2}{*}{ Kesimpulan } \\
\hline & $\begin{array}{c}\text { Kualitas } \\
\text { Pelayanan }\end{array}$ & Harga & $\begin{array}{c}\text { Loyalitas } \\
\text { Pelanggan }\end{array}$ & & \\
\hline Inst. 1 & 0.511 & 0.443 & 0.345 & 0.300 & Valid \\
\hline Inst. 2 & 0.455 & 0.501 & 0.521 & 0.300 & Valid \\
\hline Inst. 3 & 0.495 & 0.662 & 0.453 & 0.300 & Valid \\
\hline Inst. 4 & 0.442 & 0.534 & 0.469 & 0.300 & Valid \\
\hline Inst. 5 & 0.566 & 0.552 & 0.651 & 0.300 & Valid \\
\hline Inst. 6 & 0.563 & 0.622 & 0.693 & 0.300 & Valid \\
\hline Inst. 7 & 0.491 & 0.501 & 0.585 & 0.300 & Valid \\
\hline Inst. 8 & 0.549 & 0.448 & 0.606 & 0.300 & Valid \\
\hline Inst. 9 & 0.478 & - & - & 0.300 & Valid \\
\hline Inst. 10 & 0.467 & - & - & 0.300 & Valid \\
\hline
\end{tabular}

Sumber: Data primer, 2019

Berdasarkan Tabel 2, dapat dilihat dan disimpulkan bahwa dari semua butir pernyataan variabel kualitas pelayanan, harga dan loyalitas pelanggan hasilnya adalah valid.

\section{Uji Reliabilitas}

Pengujian reliabilitas ini dilakukan untuk menguji seberapa jauh hasil pengukuran yang dapat diandalkan secara konsisten. Pada tabel hasil pengujian reliabilitas berikut, diketahui bahwa semua variabel mempunyai alpha di atas 0,6 yang berarti bahwa semua variabel dalam penelitian ini dapat diandalkan.

Tabel 3: Hasil Uji Reliabilitas Variabel

\begin{tabular}{lcc}
\hline \multicolumn{1}{c}{ Variabel } & Cronbach's Alpha & Keterangan \\
\hline Kualitas Pelayanan & 0.667 & Reliabel \\
Harga & 0.641 & Reliabel \\
Loyalitas Pelanggan & 0.659 & Reliabel \\
\hline Sumber: Hasil pengolahan data, 2019 &
\end{tabular}

Berdasarkan Tabel 3, dapat dilihat dan disimpulkan bahwa nilai Cronbach's Alpha positif dimana lebih besar dari 0,6 yang merupakan batas minimal koefisien reliabilitas dapat dianggap baik. Dengan demikian, dikatakan bahwa pernyataan di atas reliabel. 


\section{Analisis Hasil Penelitian}

Tabel 4: Pengaruh Kualitas Pelayanan dan Harga Terhadap Loyalitas Pelanggan Hubungan Parameter Variabel Mult. R Square Konstanta Koef. R Regresi

\begin{tabular}{lllllll}
\hline Kualitas Pelayanan & \multirow{2}{*}{0.884} & \multirow{2}{*}{0.782} & \multirow{2}{*}{0.358} & $\begin{array}{l}0.628 \\
0.228\end{array}$ & $\begin{array}{l}0.000 \\
0.029\end{array}$ & \multirow{2}{*}{0.05} \\
Harga & & & & \\
\hline
\end{tabular}

\section{Pengujian Signifikansi}

F hitung $>$ F tabel $=105.965>3.153$

Keterangan: Variabel Loyalitas Pelanggan

Sumber: data diolah 2019

Berdasarkan Tabel 4, Nilai F hitung sebesar 105,965 > F tabel 3,153, artinya secara bersama-sama kualitas pelayanan dan harga berpengaruh signifikan pada tingkat nyata 95\% terhadap loyalitas pelanggan botol minum herbalife pada online shop di Pondok Gede Barat Bekasi, maka Ho ditolak dan Ha diterima yang berarti bahwa variabel bebas: kualitas pelayanan dan harga secara simultan berpengaruh positif dan signifikan terhadap loyalitas pelanggan. Dengan demikian hipotesis pertama secara statistik dapat diterima atau teruji.

Nilai koefisien determinasi $\left(\mathrm{R}^{2}\right)$ sebesar 0.782 , artinya kualitas pelayanan dan harga secara bersama-sama memberikan kontribusi sebesar 78,2\% kepada loyalitas pelanggan, sedangkan sisanya sebesar $21,8 \%$ disumbangkan faktor lain yang tidak dibahas dalam penelitian ini.

$$
\text { Persamaan Regresi } \mathrm{Y}=0,358+0,628\left(\mathrm{X}_{1}\right)+0,228\left(\mathrm{X}_{2}\right)
$$

Kualitas pelayanan dan harga berpengaruh positif dan signifikan terhadap loyalitas pelanggan botol minum herbalife pada online shop di Pondok Gede Barat Bekasi, pada tingkat nyata 95\%. Koefisien kualitas pelayanan sebesar 0,628, artinya jika ada peningkatan kualitas pelayanan, maka loyalitas pelanggan botol minum herbalife pada online shop di Pondok Gede Barat Bekasi akan meningkat atau sebaliknya dengan asumsi harga tidak berubah. Koefisien harga sebesar 0,228, artinya jika ada peningkatan harga, maka loyalitas pelanggan botol minum herbalife pada online shop di Pondok Gede Barat Bekasi, akan meningkat atau sebaliknya, dengan asumsi kualitas pelayanan tidak berubah.

Tabel 5: Pengaruh Kualitas Pelayanan Terhadap Loyalitas Pelanggan

\begin{tabular}{ccccccc}
\hline Variabel & \multicolumn{6}{c}{ Parameter } \\
\cline { 2 - 6 } & $\mathbf{R}$ & R Square & Konstanta & $\begin{array}{c}\text { Koef. } \\
\text { Regresi }\end{array}$ & Sig. & $\boldsymbol{\alpha}$ \\
\hline $\begin{array}{c}\text { Kualitas } \\
\text { Pelayanan }\end{array}$ & 0.874 & 0.764 & 2.993 & 0.750 & 0.000 & 0.05 \\
\hline
\end{tabular}

Pengujian Signifikansi

$\mathrm{t}$ hitung $>\mathrm{t}$ tabel $=13.925>2.000$

Keterangan: Variabel Loyalitas Pelanggan

Sumber: data diolah 2019

Berdasarkan Tabel 5, nilai koefisien determinasi $\left(\mathrm{R}^{2}\right)$ sebesar 0.764 , artinya kualitas pelayanan memberikan kontribusi sebesar $76,4 \%$ terhadap loyalitas pelanggan botol minum herbalife pada online shop di Pondok Gede Barat Bekasi, sedangkan sisanya sebesar 23,6\% disumbangkan faktor lain yang tidak diteliti, seperti harga. 
Persamaan Regresi $\mathrm{Y}=2,993+0,750\left(\mathrm{X}_{1}\right)$

Kualitas pelayanan berpengaruh positif dan signifikan pada tingkat nyata $95 \%$ terhadap loyalitas pelanggan botol minum herbalife pada online shop di Pondok Gede Barat Bekasi. Koefisien kualitas pelayanan sebesar 0,750, artinya jika ada peningkatan kualitas pelayanan, maka loyalitas pelanggan botol minum herbalife pada online shop di Pondok Gede Barat Bekasi akan meningkat atau sebaliknya. Untuk menguji hubungan parsial variabel kualitas pelayanan terhadap loyalitas pelanggan signifikan atau tidak, dilakukan pengujian $\mathrm{t}$ hitung dibandingkan dengan $\mathrm{t}$ tabel dengan tingkat kepercayaan $(\alpha)=$ 0.05 , hasilnya adalah $\mathrm{t}$ tabel $=2,000$ yang dilihat dari tabel distribusi $\mathrm{t}$ (derajat kebebasan $=$ $\mathrm{n}-2 ;(62-2=60)$, dengan uji dua pihak). Berdasarkan perhitungan tersebut di atas dapat dinyatakan bahwa nilai $t_{\text {hitung }}=13,925$ dibandingkan dengan $t_{\text {tabel }} 2,000$ atau $t_{\text {hitung }}>t_{\text {tabel }}$ $(13,925>2,00)$, maka Ho ditolak dan Ha diterima, dapat diartikan terdapat pengaruh yang signifikan kualitas pelayanan terhadap loyalitas pelanggan botol minum herbalife pada online shop di Pondok Gede Barat Bekasi. Dengan demikian hipotesis kedua secara statistik dapat diterima atau teruji.

Tabel 6: Pengaruh Harga Terhadap Loyalitas Pelanggan

\begin{tabular}{ccccccc}
\hline Variabel & \multicolumn{6}{c}{ Parameter } \\
\cline { 2 - 6 } & $\mathbf{R}$ & R Square & Konstanta & $\begin{array}{c}\text { Koef. } \\
\text { Regresi }\end{array}$ & Sig. & $\boldsymbol{\alpha}$ \\
\hline Harga & 0.724 & 0.525 & 5.229 & 0.839 & 0.000 & 0.5 \\
\hline
\end{tabular}

Pengujian Signifikansi

$\mathrm{t}$ hitung $>\mathrm{t}$ tabel $=8.138>2.000$

Keterangan: Variabel Loyalitas Pelanggan

Sumber: data diolah 2019

Berdasarkan Tabel 6, nilai koefisien determinasi $\left(\mathrm{R}^{2}\right)$ sebesar 0.525 , artinya harga memberikan kontribusi sebesar 52,5\% terhadap loyalitas pelanggan botol minum herbalife pada online shop di Pondok Gede Barat Bekasi, sedangkan sisanya sebesar 47,5\% disumbangkan faktor lain yang tidak diteliti, seperti kualitas pelayanan.

$$
\text { Persamaan Regresi } \mathrm{Y}=5,229+0,839\left(\mathrm{X}_{2}\right)
$$

Harga berpengaruh signifikan pada tingkat nyata $95 \%$ terhadap loyalitas pelanggan botol minum herbalife pada online shop di Pondok Gede Barat Bekasi. Koefisien harga sebesar 0,839 , artinya jika ada peningkatan harga, maka loyalitas pelanggan botol minum herbalife pada online shop di Pondok Gede Barat Bekasi akan meningkat atau sebaliknya. Untuk menguji hubungan parsial variabel harga terhadap loyalitas pelanggan signifikan atau tidak, dilakukan pengujian $\mathrm{t}$ hitung dibandingkan dengan $\mathrm{t}$ tabel dengan tingkat kepercayaan $(\alpha)=0.05$, hasilnya adalah $\mathrm{t}$ tabel $=2,000$ yang dilihat dari tabel distribusi $\mathrm{t}$ (derajat kebebasan $=n-2 ;(62-2=60)$, dengan uji dua pihak). Berdasarkan perhitungan tersebut di atas dapat dinyatakan bahwa nilai $\mathrm{t}$ hitung $=8,138$ dibandingkan dengan $\mathrm{t}$ tabel 2,000 atau $t_{\text {hitung }}>\mathrm{t}_{\text {tabel }}(8,138>2,00)$, maka Ho ditolak dan Ha diterima, dapat diartikan terdapat pengaruh yang signifikan harga terhadap loyalitas pelanggan botol minum herbalife pada online shop di Pondok Gede Barat Bekasi. Dengan demikian hipotesis ketiga secara statistik dapat diterima atau teruji. 


\section{Pembahasan}

\section{Pengaruh Kualitas Pelayanan dan Harga Terhadap Loyalitas Pelanggan}

Berdasarkan hasil analisis diketahui bahwa kualitas pelayanan dan harga dapat mendorong peningkatan loyalitas pelanggan botol minum herbalife pada online shop di Pondok Gede Barat Bekasi. Hasil penelitian ini sama dengan hasil penelitian yang dilakukan oleh Bulan, (2016) dan Bakkara \& Wibowo, (2016), yaitu menganalisis pengaruh kualitas pelayanan dan harga terhadap loyalitas pelanggan.

\section{Pengaruh Kualitas Pelayanan Terhadap Loyalitas Pelanggan}

Hasil penelitian ini menunjukkan bahwa kualitas pelayanan dapat mendorong peningkatan loyalitas pelanggan. Hal ini dikarenakan bahwa keandalan karyawan cekatan dalam menangani kebutuhan akan pesanan, memberikan perhatian serius terhadap pelanggan, daya tanggap terhadap pesanan pelanggan cepat dikirim, tidak membiarkan pelanggan menunggu terlalu lama, adanya jaminan terhadap pelanggan akan rasa aman dan nyaman, kesoponan karyawan dalam melayani pelanggan, memberikan perhatian penuh pada pelanggan, ada hubungan yang harmonis dengan pelanggan, memiliki kemasan produk yang menarik, dan karyawan berpenampilan rapih saat bekerja. Hasil penelitian ini sesuai dengan penelitian yang dilakukan oleh Bulan, (2016), yaitu menganalisis pengaruh kualitas pelayanan terhadap loyalitas pelanggan.

\section{Pengaruh Harga Terhadap Loyalitas Pelanggan}

Hasil penelitian ini menunjukkan bahwa harga dapat mendorong peningkatan loyalitas pelanggan. Hal ini dikarenakan bahwa keterjangkauan harga botol minum herbalife oleh pelanggan, perusahaan menetapkan harga yang dapat dibeli pelanggan, harga sesuai dengan kemampuan pelanggan, mahal murahnya harga menjadi pertimbangan pelanggan, harga yang tinggi sesuai dengan kualitas produk, harga sudah sesuai dengan kualitas produk, manfaat produk sesuai dengan harganya, dan jika pelanggan merasa manfaatnya kurang kemungkinan kecil pelanggan membelinya. Hasil penelitian ini sejalan dengan penelitian yang dilakukan oleh Winata dan Fiqri, (2017), yaitu menganalisis pengaruh harga terhadap loyalitas pelanggan.

\section{KESIMPULAN DAN SARAN}

\section{Kesimpulan}

Berdasarkan hasil analisis dalam penelitian ini, maka dapat ditarik beberapa kesimpulan dalam penelitian ini: 1). Variabel kualitas pelayanan dan harga berpengaruh positif dan signifikan terhadap loyalitas pelanggan botol minum herbalife di Pondok Gede Barat. Unsur temuan dari penelitian ini adalah kehandalan karyawan yang cekatan dalam menangani kebutuhan akan pesanan pelanggan disamping itu harga botol minum herbalife yang ditetapkan oleh perusahaan dapat dibeli oleh pelanggan, hal ini yang menjadi mengapa para pelanggan menjadi loyal terhadap botol minum herbalife. 2). Variabel kualitas pelayanan berpengaruh signifikan terhadap loyalitas pelanggan botol minum herbalife di Pondok Gede Barat. Unsur temuan dari hasil penelitian ini adalah bahwa semakin tinggi kehandalan karyawan dalam memberikan pelayanan pada pelanggan dan juga daya tanggap perusahaan terhadap nasabah dimana semua pesanan yang diminta oleh pelanggan dengan segera dan secepat mungkin dapat dikirim. Artinya perusahaan memperhatikan penuh kebutuhan para pelanggannya. 3). Variabel harga berpengaruh signifikan terhadap loyalitas pelanggan botol minum herbalife di Pondok Gede Barat. 
Unsur temuan dari hasil penelitian ini adalah bahwa walaupun harganya mengalami kenaikkan pelanggan tetap loyal mengingat kualitas produk botol minum herbalife dapat terjangkau oleh pelanggan dan juga manfaat dari produknya sesuai dengan yang diharapkan oleh pelanggan.

\section{Saran}

Untuk peneliti lain yang ingin meneliti faktor-faktor yang mempengaruhi loyalitas pelanggan dalam bisnis online shop disarankan untuk menambah variabel bebas yang lain, selain yang ada pada penelitian ini agar dapat menambah informasi faktor-faktor yang mempengaruhi loyalitas pelanggan dalam bisnis online shop. Objek penelitian juga tidak hanya dalam bisnis online shop, peneliti lain bisa mengambil penelitian pada dunia perbankan, property dan industry lainnya. Penelitian diharapkan menggunakan data yang terbaru yang sudah di valid dan dengan jumlah data yang lebih banyak dengan mengambil rentang waktu yang lebih panjang, sehingga dapat menggambarkan keadaan yang lebih jelas pada saat penelitian trsebut.

Untuk Online shop botol minum herbalife sebagai objek penelitian ini, diharapkan dengan hasil penelitian ini akan dapat meningkatkan pelanggan lebih menjadi loyal sehingga tujuan utamanya dapat terpenuhi. Dari hasil penelitian ini Online shop botol minum herbalife dapat memperhatikan beberapa faktor-faktor yang mempengaruhi loyalitas pelanggan, pertama harus selalu memperhatikan keinginan para pelanggan, berikan pelayanan yang terbaik dan jadikan pelanggan sebagai raja dalam membeli produk botol minum herbalife, lalu harga dapat terjangkau yang disesuaikan dengan kemampuan pelanggan, kualitas produk terus ditingkatkan dan berikan manfaat lebih atas produk tersebut kepada para pelanggan.

\section{DAFTAR PUSTAKA}

Bakkara, Arfiyanti dan Wibowo, Edwin Agung. 2016. “Analisis Pengaruh Kualitas Pelayanan dan Harga Terhadap Loyalitas Pelanggan Provider XL Pada Mahasiswa Fakultas Ekonomi Iniversitas Riau Kepulauan, Batam”. Jurnal Bening, 3 (1) 2016. 74-86, Juni 2016. ISSN Cetak: 2252-52672.

Brown, Keith. 1999. Service Quality .Cambidge: Elsiver.

Bulan, Tengku Putri Lindung. 2016. "Pengaruh Kualitas Pelayanan dan Harga Terhadap Loyalitas Konsumen Pada PT. Tiki Jalur Nugraha Ekakurir Agen Kota Langsa". Jurnal Manajemen dan Keuangan, Vol. 5, No. 2, Nopember 2016, ISSN: 2252-844X, hal. 592-602.

Griffin, Jill. 2005. Customer Loyalty: Menumbuhkan dan Mempetahankan Kesetiaan Pelanggan. Edisi Revisi dan Terbaru. Diterjemahkan oleh Dr. Dwi Kartini Yahya. Jakarta : Penerbit Erlangga.

Hurriyati, Ratih. 2010. Bauran Pemasaran dan Loyalitas Konsumen. Bandung : Penerbit Alfabeta

Kotler, Philip. 2013. Manajemen Pemasaran. Edisi tiga belas Bahasa Indonesia. Jilid 1 dan 2. Jakarta : Penerbit Erlangga.

Kotler, Philip dan Gary Armstrong. 2012. Prinsip-Prinsip Pemasaran, Jilid 1, Edisi 12. Jakarta: Penerbit Erlangga.

Lau, Geok Then and Lee, Sook Han. 1999. "Consumers Trust in a Brand and the Link to Brand Loyalty". Journal of Market Focused Management.

Lupiyoadi, Rambat. 2013. Manajemen Pemasaran Jasa. Edisi 3. Jakarta: Penerbit Salemba Empat. 
Mowen, John C., Michael Minor. 2002. Perilaku Konsumen. Jakarta: Penerbit Erlangga.

Parasuraman, A, Zeithaml, V.A \& Berry, L.L. 2007. Reassessment of Expectations as a Comparison Standard in Measuring Service Quality: Implacations for Future Research. Journal of Marketing.

Robinette, Scott. 2001. Emotion Marketing: The Hallmark Way of Winning Customers for Life. Mc.Grow Hill Book Company.

Sugiyono. 2016. Statikstika Untuk Penelitian. Bandung: Penerbit Alfabeta.

Supranto, J. 2011. Pengukuran Tingkat Kepuasan Pelanggan Untuk Menaikan Pangsa Pasar. Jakarta : Penerbit PT. Rineka Cipta.

Swastha, Basu. 2011. Manajemen Penjualan: Pelaksanaan Penjualan. BPFE Yogyakarta.

Umar, Husein. 2011. Riset Pemasaran dan Perilaku Konsumen. Jakarta : Penerbit PT. Gramedia Pustaka Utama.

Winata, Andri dan Fiqri, Isnawan Ahlul. 2017. "Pengaruh Harga dan Kualitas Jasa Terhadap Loyalitas Pelanggan Hotel Emersia di Bandar Lampung". Jurnal Manajemen Magister, Vol. 03. No. 02 Juli 2017,hal. 133-149. 